Policy Research Working Paper 3090

\title{
The Cotonou Agreement and its Implications for the Regional Trade Agenda in Eastern and Southern Africa
}

\author{
Manuel de la Rocha
}

The World Bank

Africa Region

Regional Integration and Cooperation Unit

June 2003 


\begin{abstract}
Subregional trade arrangements (RTAs) in Eastern and Southern Africa have proliferated in the past 10 to 15 years. The small size of most of the countries in the region, some of which are landlocked, and the security needs in the post independence period largely explain the rapid expansion. These arrangements are characterized by multiple and overlapping memberships, complex structures, and eventually, conflicting and confusing commitments. The influence of RTAs has been limited to assisting the region in increasing trade, attracting foreign direct investment, enhancing growth, and achieving convergence among member countries. But despite their limitations, RTAs have the potential, if properly designed and effectively implemented, to be an important instrument in integrating member countries into global markets. In 1998 most of the Southern African countries, as members of the Africa Caribbean
\end{abstract}

Pacific group (ACP), signed the Cotonou Agreement with the European Union, which includes the negotiation of economic partnership agreements (EPAs) between the EU and the ACP. The Cotonou Agreement explicitly leaves to the ACP countries to decide the level and procedures of the EPA trade negotiations, taking into account the regional integration process. This raises the question of how to decide on the groupings in the context of conflicting regional trade agendas. De la Rocha argues that the Cotonou Agreement and EPA negotiations could become the external driving force that will push the regional organizations to rationalize and harmonize their regional trade arrangements, thus strengthening the integration process and economies of the region, and assisting the Eastern and Southern Africa region in becoming a more active partner in the global economy.

This paper-a product of the Regional Integration and Cooperation Unit, Africa Region-is part of a larger effort in the region to contribute to the debate on regional integration in Africa. Copies of the paper are available free from the World Bank, 1818 H Street NW, Washington, DC 20433. Please contact Fatimata Sy, room J5-280, telephone 202-458-9750, fax 202-473-8276, email address fksy@worldbank.org. Policy Research Working Papers are also posted on the Web at http://econ.worldbank.org. The author may be contacted at mdelarocha@worldbank.org. June 2003. (25 pages)

The Policy Research Working Paper Series disseminates the findings of work in progress to encourage the exchange of ideas about development issues. An objective of the series is to get the findings out quickly, even if the presentations are less than fully polished. The papers carry the names of the authors and should be cited accordingly. The findings, interpretations, and conclusions expressed in this paper are entirely those of the authors. They do not necessarily represent the view of the World Bank, its Executive Directors, or the countries they represent. 


\title{
The Cotonou Agreement and its Implications for the Regional Trade Agenda in Eastern and Southern Africa
}

\author{
Manuel de la Rocha ${ }^{1}$
}

'World Bank, African Region, mdelarocha@worldbank.org. May 23, 2003. 



\section{The Cotonou Agreement and its Implications for the Regional Trade Agenda in Eastern and Southern Africa ${ }^{2}$}

\section{Introduction}

One of the recent key characteristics that define the process of economic integration in the Eastern and Southern Africa (ESA) region ${ }^{3}$ is the development and proliferation of overlapping and inconsistent regional trade agreements, namely the Southern African Customs Union (SACU), Southern African Development Community (SADC), Common Market of Eastern and Southern Africa (COMESA) and the East African Community (EAC). These arrangements are supplemented by other regional arrangements such as Regional Investment Facilitation Forum (RIFF) and the Common Monetary Area (CMA) and others that, although of a non-trade nature, have economic integration among their main objectives, such as the Indian Ocean Commission (IOC). As shown in Figure 1, most of the countries in the region belong to at least two of these regional groups. For instance, South Africa and Botswana are members of both SADC and SACU, Namibia and Swaziland participate in three regional trade agreements as well as RIFF $^{4}$ and are part of the common monetary area, Kenya and Uganda are members of both COMESA and EAC.

Figure 1. Regional Trade Agreements (RTAs) in Eastern and Southern Africa

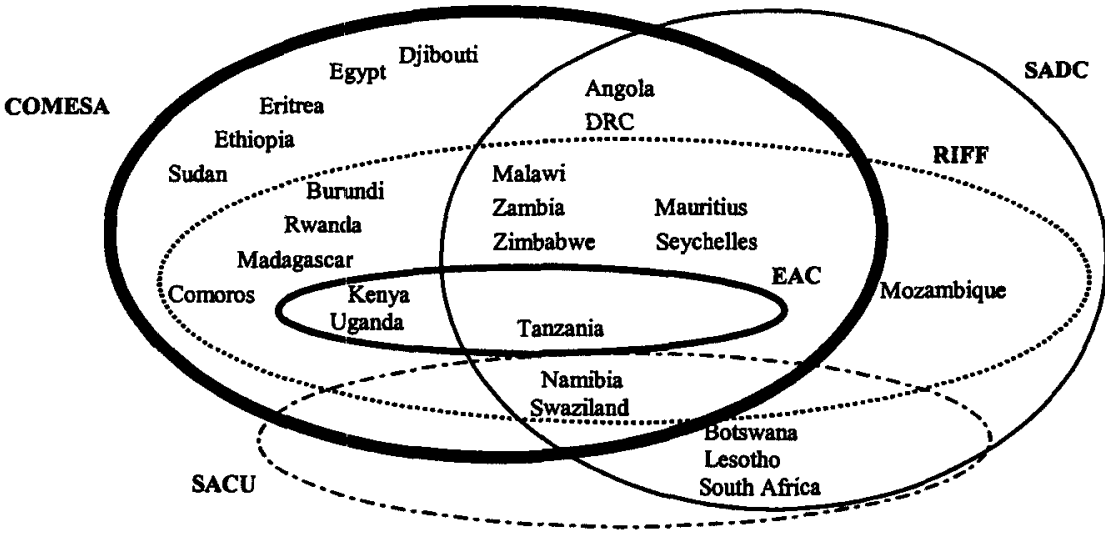

$$
\begin{aligned}
& \text { RIFF } \\
& \text { COMESA Common Market for Eastern and Southern Africa } \\
& \text { EAC Commission for East African Co-operation } \\
& \text { SADC _ Southem African Development Community } \\
& \text { SACU }
\end{aligned}
$$

\footnotetext{
${ }^{2}$ Thanks to Alan Gelb, Enrique Aldaz, Marie-Francoise Marie-Nelly, Marcelo Olarreaga, Claire Thirriot and Lucio Castro for their valuable comments.

${ }^{3}$ Under ESA region we refer to all countries belonging to COMESA and SADC, namely: Angola, Botswana, Burundi, Congo DR, Djibouti, Egypt, Eritrea, Kenya, Lesotho, Malawi, Mauritius, Mozambique, Namibia, Rwanda, Seychelles, South Africa, Sudan, Swaziland, Tanzania, Uganda, Zambia and Zimbabwe.

${ }^{4}$ Previously known as the Cross Border Initiative (CBI)
} 
The majority of these RTAs in ESA have proliferated in the past 10 to15 years. The small size of most of the countries in the region, some of which are landlocked, and the security needs in the post independence period largely explain the rapid expansion. Their proliferation has occurred not only in the number of them, but also in their variety, in terms of objectives, design, and the speed of integration envisaged.

In addition, most countries in the region, especially in Southern Africa are engaged in or considering bilateral trade and investment agreements. Malawi, Mozambique, and Zimbabwe respectively have seven and eight and ten bilateral agreements with another SADC country. Angola has six, while South Africa and Botswana have four bilateral trade agreements with another SADC member state. Significant differences in the interpretation and enforcement of the terms and conditions of these bilateral trade agreements represent an obstacle for the local industries serving markets covered by them.

As a result, despite the strong political rhetoric supporting them, the RTAs have failed to increase trade, attract foreign direct investment, enhance growth, or achieve convergence among the member countries (UNCTAD 2002). In fact, the region has been marginalized in the global economy: it under-trades, and the degree to which it under trades has steadily increased since the 1980 s leading to substantial fall in its share of world trade (Gelb 2002). Reversal of its marginalization in world trade is essential to accelerate growth, expand employment, and reduce poverty in the region. The RTAs can, if properly designed and effectively implemented, be an important instrument to assist the member countries in integrating with global markets.

There is a growing awareness of the economic costs, in terms of efficiency, administration and lack of transparency, that the existing "spaghetti bowl" imposes on many of the countries and business in the region. However, there are a number of historical, political and cultural reasons that explain the current configuration of the regional trade agreements and their membership. Failure to address these issues along with the economic issues have prevented all attempts to rationalize the current RTAs.

A window of opportunity is now open for these RTAS through the Cotonou Agreement recently signed between the European Union and the African, Caribbean and Pacific group (ACP), which will have very important implications for the regional integration process in Eastern and Southern African. Many authors have argued that the Economic and Partnership Agreements to be negotiated as part of the Agreement will impose large costs on developing countries. This paper will argue that, despite its risks, EPAs could also generate very important benefits for Eastern and Southern African countries - in particular their trade-related and supply side aspects- but they will not be fully exploited unless the region finally addresses some of the outstanding issues regarding its regional trade agenda. Therefore, the Cotonou Agreement can be the external impulse that leads to the rationalization of the RTAs. 
The paper is organized as follows: Section 1 briefly presents an overview of the main Regional Trade Agreements currently in place in Eastern and Southern Africa; Section 2 reviews the evolution of trade flows and trade policies in the region, focusing on the development of intra-regional trade for the two main RTAs through the 90s; Section 3 looks into some of the main costs and benefits arising from the current configuration of regional trade agreements in the region; Section 4 analyses the implications of the Cotonou Agreement for the regional trade agenda and presents a proposal to overcome some of the main problems affecting the regional trade agreement; Section 5 presents the conclusions.

\section{An overview of the Regional Trade Agenda;:}

Different historical backgrounds, political agendas and approaches to regional integration are behind the multiplicity of regional trade agreements. The key features of the four main trade agreements operating in Southern and Eastern Africa are:

- The South African Development Community (SADC) was established by the SADC Treaty in July 1992 when it replaced the Southern African Development Coordination Conference (SADCC), which was a regional cooperation forum against South Africa at the time of apartheid. Currently SADC members are South Africa, Lesotho, Botswana, Swaziland, Namibia, Angola, Mozambique, Zimbabwe, Zambia, Malawi, Mauritius, Seychelles, Tanzania and Democratic Republic of Congo (DRC). All member states have agreed to a Trade Protocol which came into force in September 2000. It envisages a SADC Free Trade Area by 2008. In the meantime, SADC countries are intending to trade on preferential terms in an asymmetrical manner under which South Africa (and indirectly its SACU partners) should open up its market faster than the other SADC members. The SADC trade liberalization and integration program makes no reference to SADC becoming a Customs Union in the near future, and therefore, for the moment the Free Trade Area is the deepest form of economic integration in the area among SADC countries. The calendar for SADC countries to eliminate its internal tariffs is spread over the 2000-2012 period. However, in the transitory period, individual member states are given the choice to implement the trade liberalization scheme at their own pace. While the idea of differential tariff reduction rate is democratic and members can be pressured to make good on commitments that they made voluntarily, there is the likelihood that some countries may not achieve the planned 100 per cent tariff reduction by the deadline date because they backloaded the bulk of their tariff cuts and started at a very low base, e.g., Tanzania (9.2 per cent), Mozambique (16.9 per cent).

- The Southern Africa Customs Union (SACU) was established in its present form in 1969 and comprises Botswana, Lesotho, Namibia, Swaziland, and South Africa. It is a fully-fledged customs union with a common external tariff, a centralized customs administration (including a central revenue collection and sharing mechanism through a negotiated and agreed formula) and a mechanism for intra-SACU consultations. Up until now SACU has no institutional setting and its tariff rates are unilaterally decided by South Africa, which also collects all the customs revenues. In exchange for yielding its trade policy to SA, the formula for the distribution of the customs duties is more 
favorable to the four small members, which receive a higher proportion of the revenues. The five SACU members have recently renegotiated the agreement and reviewed the existing formula.

- The Common Market of Eastern and Southern Africa (COMESA) is made up of the following countries, Kenya, Uganda, Egypt, Sudan, Swaziland, Namibia, Angola, Zimbabwe, Zambia, Malawi, Mauritius, Seychelles, and DRC. The COMESA Treaty was signed in 1994 as a successor for the former Preferential Trade Area (PTA). On October 31, 2000 COMESA established a FTA with the following countries: Djibouti, Egypt, Kenya, Madagascar, Malawi, Mauritius, Sudan, Zambia and Zimbabwe. As for the rest of the COMESA countries, most of them grant important preferential access to their markets to the other members, and are planning to join the FTA in the next few years. The next step for COMESA is the implementation of a customs union by 2004. To that end, a Common External Tariff (CET) has been agreed with a four-band tariff structure of $0-5-15-30$ percentage points on capital goods, raw materials, intermediate goods and finished products respectively. The tariffs may well change before the implementation of the CET but what is important is that there has been agreement on the structure of the CET, which has allowed work on the Customs Union to progress.

- The East African Community (EAC) is formed by three countries, Uganda, Kenya and Tanzania. Its treaty was signed in 1999 and is a revival of the economic cooperation agreement which broke up in 1977. The Treaty provides for a progressive regional integration process, beginning with formation of a free trade area and a customs union within four years of the signing of the Treaty. This will be followed by a Common Market, a Monetary Union and ultimately a Political Federation. EAC has set up a high task force to negotiate the details of the Customs Union, expected to be in place by January 2004.

\section{Evolution of regional trade flows in Eastern and Southern Africa}

One of the key characteristics of trade links within Eastern and Southern Africa is the low level of intra-regional trade that takes place in the region. This section will examine regional trade flows for SADC and COMESA, which combined encompass all the countries in the ESA region. Table 1 shows the change in the main trade destinations and origin for imports and exports for both regional organizations between 1991 and 2001 . Evolution of intra-regional trade flows has been quite different in the two RTAs. While COMESA intra-regional trade has overall remained marginal for the member countries, representing less than 5 per cent of the total, SADC has seen an increase in intra-regional imports from 6.3 per cent to 9.9 per cent, and exports from 7.9 to 13 per cent between 1991 and 2001. 
Table 1. Direction of trade for SADC and COMESA

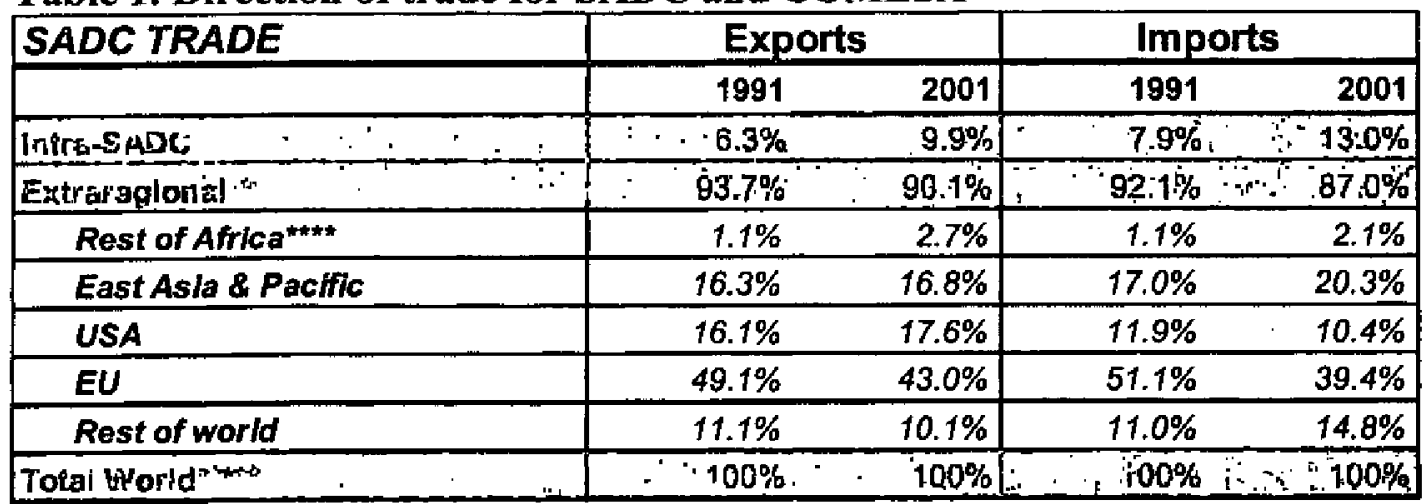

\begin{tabular}{|c|c|c|c|c|}
\hline COMESA TRADE & Expe & & Imports & \\
\hline & 1991 & 2001 & 1991 & 2001 \\
\hline Intra conies $\beta_{1}(20$ coumiries) & $3.5 \%$ & $5.4 \%$ & $2,2 \%$ & $=-3,8 \%$ \\
\hline Exirareglonal & $96.5 \%$ & $94.6 \%$ & $97.8 \% \quad \%$ & $96.2 \%$ \\
\hline Rest of Africa & $3.3 \%$ & $5.1 \%$ & $6.0 \%$ & $9.4 \%$ \\
\hline South Asia & $1.9 \%$ & $2.2 \%$ & $1.5 \%$ & $3.3 \%$ \\
\hline East Asia \& Pachflc & $9.8 \%$ & $14.5 \%$ & $14.0 \%$ & $17.8 \%$ \\
\hline$E U$ & $50.8 \%$ & $39.5 \%$ & $44.0 \%$ & $31.7 \%$ \\
\hline USA & $16.9 \%$ & $19.6 \%$ & $13.6 \%$ & $14.3 \%$ \\
\hline Rest of world & $13.8 \%$ & $13.7 \%$ & $18.8 \%$ & $19.6 \%$ \\
\hline Wyorld & $10 \% \%$ & $100 \%$ & $\because 100 \%$ & $400 \%$ \\
\hline
\end{tabular}

Source: Yagci and Aldaz-Camoll (2003)

Despite the fact that intra-regional trade as a percent of total trade has more than doubled during the 1990s for SADC countries, participation in the regional trade flows is completely unbalanced. South Africa accounts for more than 70 percent of the intraSADC imports, enjoying a large trade surplus with the other members, estimated at more than \$US4 billion per year. The BLNS countries (Botswana, Lesotho, Namibia and Swaziland), Malawi, Mozambique, Zambia, and Zimbabwe are the most dependent on imports from South Africa. Simultaneously, while South African exports to the region soared during the $90 \mathrm{~s}$, the share of the EU as the main origin of SADC imports decreased from 44 to 31.7 per cent for SADC and from 51.1 to 39 per cent in the broader COMESA space. There may be a case to suggest that the renewed engagement of SA in the region since the fall of the apartheid regime in 1994 has led to an important degree of trade diversion from European goods in favors of South African ones.

Overall, even for SADC, if South African is not taken into account, trade flows between ESA countries are still substantially low. Trade flows between ESA countries reflect the structure of production of the countries that make up the two regional groups, which is characterized by concentration of exports in a few commodities exported to international markets. Low levels of intra-regional trade are also due to the poor quality of infrastructure and financial linkages, as well as the restrictions on trade and exchange regimes adopted by most of the countries in previous decades. Indeed, in many ESA countries, the practice of multiple exchange rate systems, surrender requirements for 
export proceeds, high tariff protection, restrictive import licensing requirements, and other restrictive non-tariff barriers have limited the scope of intra-regional trade in the past. According to the IMF (2000) the overall degree of restrictiveness for the whole ESA region has been until recently relatively high; in the early 1990s it was 9.7 (on a scale from 0 to 10 , where 10 indicates the most restrictive regime). The situation has now changed to some extent as a result of the liberalization of their trade regimes. The average overall trade restrictiveness for the region has fallen from 9.7 to less than 6 in 1998. In general, SADC countries are less restrictive. As of 1998, nine out of 14 members of SADC (Botswana, the Democratic Republic of Congo, Lesotho, Malawi, Namibia, South Africa, Swaziland, Mozambique, and Zambia) had moderately open or fully open trade regimes.

Less restrictive and more liberal trade regimes have translated into more open economies. Tables $1 \& 2$ present openness indicators based on the ratios of exports to GDP and of exports plus imports to GDP for SADC and COMESA, respectively, from 1990 to 2001. Two types of exports and imports are reviewed, in terms of merchandise trade and in terms of trade in goods and services.

Table 2. Openess indicators for Eastern and Southern Africa countries (Measured as per cent of GDP)

\begin{tabular}{|c|c|c|c|c|c|c|c|c|c|c|}
\hline & Merchand & exports. & Morchand & imports & Exports of 0 & \& services & Imports of & s \& sery & Total trad & ods \& se \\
\hline & 1990 & 1999 & 1990 & 1999 & 1990 & 1999 & 1990 & 1999 & 1990 & 1999 \\
\hline Angola & 38 & 83 & 15 & 51 & 39 & 86 & 21 & 95 & 60 & 181 \\
\hline Botswan & 47 & 52 & 52 & 44 & 55 & 28 & 50 & 33 & 106 & 61 \\
\hline Bunund & 7 & 8 & 20 & 17 & 8 & 9 & 28 & 48 & 36 & 27 \\
\hline Congo & 11 & $9^{*}$ & 9 & $6^{*}$ & 30 & $24^{*}$ & 29 & $22 *$ & 59 & 46 \\
\hline Djiboutl & 6 & 4 & 51 & 50 & $41+$ & 47 & $58+$ & 61 & 98 & 108 \\
\hline Egypt, Arab & 6 & 4 & 21 & 18 & 20 & 15 & 33 & 24 & 53 & 39 \\
\hline Eritrea & & & & & $20++$ & 10 & $57++$ & 92 & 77 & 102 \\
\hline Ethiopi & 4 & & 16 & & 8 & 14 & 12 & 29 & 20 & 43 \\
\hline Kenya & 12 & 17 & 25 & 27 & 26 & 26 & 31 & 31 & 57 & 57 \\
\hline Lesoth & 10 & 19 & 109 & 86 & 17 & 24 & 122 & 95 & 139 & 119 \\
\hline Malawi & 22 & 24 & 31 & 39 & 24 & 27 & 33 & 42 & 57 & 69 \\
\hline Mauritiu & 45 & 37 & 61 & 53 & 65 & 65 & 72 & 68 & 138 & 133 \\
\hline Mozambiqu & 5 & 7 & 36 & 29 & 8 & 11 & 36 & 37 & 44 & 48 \\
\hline Namibi & 43 & 36 & 46 & 41 & 47 & 49 & 56 & 56 & 102 & 105 \\
\hline Rwand & 4 & 3 & 11 & 13 & 6 & 6 & 14 & 23 & 20 & 28 \\
\hline Seychelle & 15 & 24 & 50 & 71 & 62 & 74 & 67 & 88 & 129 & 162 \\
\hline South & 21 & 21 & 16 & 21 & 24 & 26 & 19 & 23 & 43 & 49 \\
\hline Sudan & 3 & 8 & 5 & 14 & & 8 & & 15 & 0 & 23 \\
\hline Swazilan & 66 & 70 & 79 & 85 & 76 & 74 & 76 & 80 & 152 & 164 \\
\hline Tanzani & 10 & 6 & 24 & 18 & 13 & 14 & 37 & 26 & 50 & 41 \\
\hline Ugand & 3 & 8 & 5 & 21 & 7 & 11 & 19 & 23 & 27 & 34 \\
\hline Zambia & 40 & 24 & 37 & 22 & 36 & 23 & 37 & 41 & 72 & 64 \\
\hline Zimbabw & 20 & 34 & 21 & 39 & 23 & 46 & 23 & 47 & 46 & 93 \\
\hline SADC & 31 & 35 & 53 & 54 & 42 & 49 & 58 & 76 & 113 & 128 \\
\hline COMES & 20 & 22 & 29 & 33 & 27 & 33 & 32 & 47 & 65 & 80 \\
\hline United & 7 & 8 & 9 & 11 & 10 & 11 & 11 & 13 & 21 & 24 \\
\hline Japan & 9 & 9 & 8 & 7 & 10 & 10 & 9 & 8 & 20 & 18 \\
\hline EU & 22 & 27 & 23 & 28 & 28 & 33 & 28 & 31 & 56 & 64 \\
\hline Latin Americe \& & 13 & 16 & 11 & 18 & 14 & 16 & 12 & 18 & 26 & 34 \\
\hline Middle East \& North & 32 & 23 & 25 & 20 & 33 & 30 & 35 & 28 & 68 & 58 \\
\hline Sub-Saharan & 22 & 24 & 19 & 25 & 27 & 28 & 26 & 31 & 53 & 60 \\
\hline World & 16 & 18 & 16 & 19 & 20 & 23 & 20 & 23 & 40 & 46 \\
\hline
\end{tabular}

Independently of which openness indicator is used, it is clear that SADC countries have increased their openness and so has the SADC as a region. For COMESA countries, more than half of its members (mostly those that are also members of SADC) experienced 
greater openness during this period, while the remaining countries experienced a fall in openness. Note that SADC countries and the SADC region have greater levels of openness than other regions - which is due to the small size of their domestic markets and that the change in openness experienced during this period was greater than most other regions.

However, greater openness has not resulted in deeper integration into the global markets, but quite the opposite. Figure 2 shows the evolution of exports from Eastern and Southern Africa as a share of global exports. As can be observed, ESA region has been increasingly marginalized from world trade. In 1990, total exports from ESA represented around 1.05 per cent of total world exports; one decade later in 2002 they were $0.96 \mathrm{per}$ cent. By RTAs, while SADC has barely maintained its share in world trade, COMESA has seen its exports falling from 0.59 to 0.44 of world exports. The main difference between the two groupings is accounted for by South Africa, which exports increased notably after the change of regime in 1994. Overall, therefore, for Eastern and Southern Africa, the 90 s can be easily considered as a "lost decade" in terms of integration into the global economy.

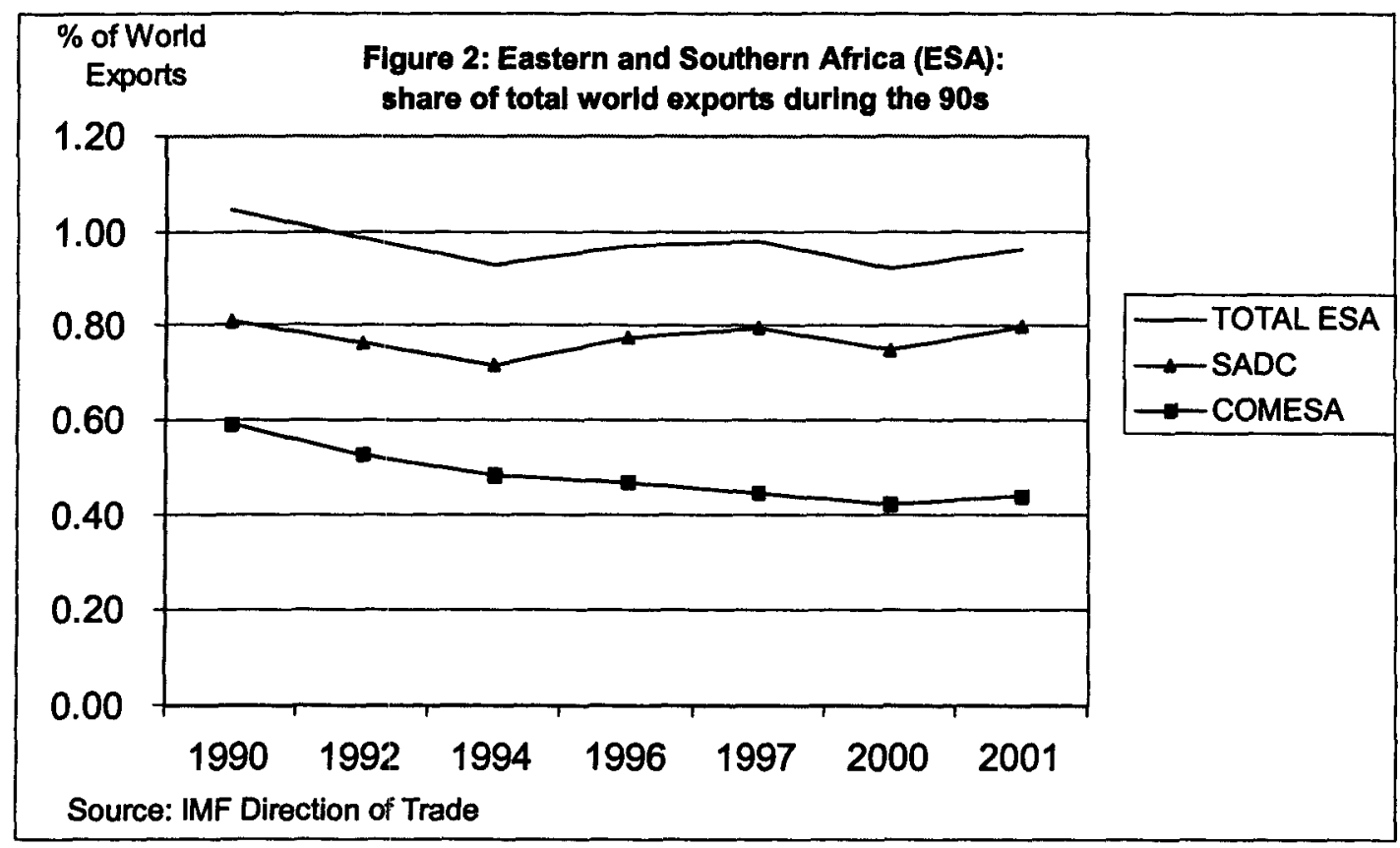

\section{Regional Trade Agreements in Eastern and Southern Africa: stepping stones or stumbling blocks to integration into the world economy?}

Data from the previous section indicates that the proliferation of preferential trade agreements and the generalized movement towards trade liberalization in most countries during the 90s has proven quite ineffective in substantially increasing the level of intraregional flows. The reality is that most countries in the region may not be natural trading partners because they have similar factor endowments and consequently, tend to export and import similar goods (Wood and Mayer 2001). Similar factor endowments across 
countries does not necessarily imply that there is no scope for trade. It can be of intraindustry nature as is the case for most trade between developed countries (trade between USA and EU, or within the EU). However, this does not fully apply to the ESA region. Given the preponderance of primary commodities in the production and exports of the countries in the region, the potential for intra-industry trade among them is somehow limited.

Yet, trade and market integration can be a very useful strategy to increase investment in member countries through their potential to reduce distortions, enlarge markets, and enhance the credibility of economic and political reforms. Such benefits are most likely when countries or their endowments are small, limiting market size. For countries in Eastern and Southern Africa increased amounts of foreign investment are essential in order to receive the transfer of technology and know-how and to create the backward linkages with local industries that will enable them raise their productivity and competitiveness, achieve product diversification, expand trade in global markets and ultimately achieve higher growth. There is evidence that FDI inflows can be induced by regional arrangements in cases where they can obtain access to significant markets and markets of industrialized countries (Robson 1998, World Bank 2000). Smaller countries lacking such links may find themselves increasingly marginalized from international capital flows. Other potential benefits or regional arrangements include stronger commitment to reforms, increased bargaining power, enhanced cooperation, and greater security. But theoretical and empirical analyses show that these benefits are neither automatic nor necessarily large. The bottom line is that regional integration arrangements must be viewed as a means to the end of improving welfare in participating countriesnot as an end in themselves.

For all this to happen ESA countries must move from the old regional schemes based on the promotion of industrial development through import substitution behind high tariff barriers towards a new outward-looking regionalism centered on export promotion and integration into global markets. Hence, the main question arising is how the regional economic arrangements present in ESA are contributing to enhance the integration of the sub-region into the global economy, what are the main constrains they present in their current fashion and what can be done about it.

Regional Trade Agreements in ESA are considered to be South-South RTAs. Recent literature shows that, although South-South RTAs can be particularly effective in encouraging liberalization of domestic markets and removing invisible barriers to trade, they are more likely, if not properly designed and effectively implemented, to lead to trade diversion and asymmetric distribution of benefits and costs, than south-north or north-north agreements (World Bank 1999). This means that agreements between developing countries comprising a poorer one and another relatively richer, with a more developed manufacturing sector, tend to be more beneficial to the latter than to the former. Typically, following the fall of preferential tariff rates the least developed members increase their imports of manufactured products from the more developed partners, whose firms may not be internationally competitive. The most likely outcome is 
that prices do not fall and producers from the exporter country capture most of the foregone tariff revenue.

Asymmetric distribution can also be caused by agglomeration effects. Industry and new investments tend to concentrate in the more developed member in the regional block once the trade barriers are removed. If not corrected with a workable compensation mechanism they can generate tensions among members. Indeed, past experiences have shown that perceptions in many countries that gains and costs are very unevenly distributed easily result in the lack of implementation of regional commitments, or in the break up of the arrangements in the most extreme cases. There are signs that such phenomena of trade diversion and asymmetry could be developing in the region particularly in SACU and SADC where as we saw South Africa, the richest country in the region, dominates trade ${ }^{5}$ (over 50 percent of total intra-block imports are from South Africa). Misgivings that Kenya is reaping all the benefits from the integration process have also bogged down negotiations on regional trade liberalization within the EAC.

Given the fact that the establishment of structural funds à la Union Europèan involving massive transfers of funds from the richer to the poorer countries is not something that could be expected among developing countries, a key step to minimize these trade diversion or agglomeration effects is to lower protection against non-members. The lower the marginal difference between world and domestic prices the less the incentives for trade diversion and subsequent transfers from the poorer to the richer country.

For Eastern and Southern Africa to reap all the benefits of deeper integration and reduce the risks of trade diversion and agglomeration it will need to address sooner rather than later some of the problems stemming from the conflicting and overlapping regional trade agenda.

First, some countries face conflicting obligations. COMESA plans to have a customs union in place by 2004; EAC plans to also have its own customs union and free trade area in place by 2004; SACU is already a customs union; and SADC plans to have a free trade area in place by 2008. As noted, a free trade area implies that imports from one member of the FTA to another rnember of the FTA are free of duty. On the other hand a customs union implies that all countries belonging to the customs union apply the same tariffs on all imports into the customs union, meaning that if a product imported from outside the customs union attracts a duty of 20 per cent then all the countries in the customs union must apply a duty of 20 per cent on the imported product after which the product can move within the countries of the customs union free of duty. As each member of a customs union needs to apply the same tariff, it follows that one country cannot be a member of two customs unions.

In this situation, members of a future customs union (i.e. COMESA) will not be able to offer preferences to non-members with whom they are partners in another free trade

\footnotetext{
${ }^{5}$ This is not completely obvious, since SA's ascension as a leading regional exporter has coincided with the end of the apartheid and the associated trade blockade. Therefore, it could be the case that for some products SA is indeed the world most competitive exporter.
} 
arrangement. If COMESA or EAC become a CU in 2004 as planned, countries in those organizations that are also participating in the SADC FTA implementation program may well be in violation of GATT Article XXIV if they seek to maintain preferential tariffs for imports from the SADC countries.

Following the same pattern, for Namibia and Swaziland, their joint membership of COMESA and SACU has become more acute now with the introduction of the COMESA FTA. These countries have been unable to implement preferential tariffs for other COMESA countries and cannot introduce free trade for imports from other COMESA countries in terms of the FTA. The Common External Tariff (CET) of the SACU agreement cannot be broken by some members granting preferences in terms of other FTA regimes, unless all the other members give their consent. Botswana and SA have not given their consent to such action by Namibia and Swaziland, because once the CET wall is broken it would be very difficult to prevent goods illegally crossing to other SACU members without payment of duty. This is probably also in violation of General Agreement on Trade and Tariffs (GATT) Article XXIV paragraph 8 (a) (ii). This situation is creating ambiguity over which RTA will prevail in practice.

Second, a further manifestation of a conflicting and confusing regional trade agenda has to do with the rules of origin and customs procedures embedded in the agreements. Different trade agreements have adopted different and also conflicting rules of origin. COMESA's rules of origin apply across the board and are based on minimum value added requiring that local materials constitute at least $35 \%$ of the value added in order for the product to be considered as local and therefore, benefit from the preferential tariffs. On the other hand, many SADC rules of origin are sector specific, and include specific requirements for different sectors and products. For example for textiles and garments, SADC rules of origin require a double transformation in order to qualify for tariff preferences -garments must be made from regionally produced textiles, fabric must be made from regional produced yarns, yarn must be made from uncarded, uncombed fibre or from chemical products. Other example of restrictive rules of origin are Coffee, Tea and Spices where at least 60 per cent by weight of the raw materials must be wholly originated in the region.

Such restrictive rules of origin are very difficult to satisfy for most regional garment producers. Some of SADC rules of origin are still pending final ratification by the countries and there are a few sectors whose negotiations are still ongoing. EAC is currently negotiating the rules of origin under its planned customs union based on a combination of COMESA and SADC ones. The rules of origin that are most commonly used at the moment by the operators across the region are those of COMESA, which have the advantages of their simplicity, low verification costs, and low protectionist level. However, once the EAC Customs Union is in place and SADC rules of origin are finalized, potential conflicting and confusing situations may arise over which trade agreement should govern trade operations within the region. On customs procedures, both SADC and COMESA have their own customs documentation, further complicating the situation. 
Implementation is difficult for all countries belonging to more than one RTA because of the complexity of obligations and wide variations in rules of origin, tariff structure, nontariff barriers (NTBs), speed of adjustment, custom procedures, etc., which creates an uncertain business environment that obstructs investment and marketing decisions and elicits corruption and bribery practice at the borders. Moreover, the management and administration of all these trade agreements are becoming a heavy burden on the limited institutional, diplomatic and negotiating capacity and resources in member countries.

Solutions to this "spaghetti bowl" are not easy. The necessary rationalization of the regional trade agreements should ensure that they become stepping stones to greater openness and development, rather than vehicles for protection and unintended inefficiency. Rationalization of the current situation through consolidation, possibly in a single arrangement, is something that should be considered. Sometimes political forces against regional integration are very strong and a radical merger may not be possible. However, if merger is not yet politically feasible, countries need to focus on choices of design to minimize the economic costs of the present arrangements. This would include rapid progress on external liberalization and deepening and widening of the arrangements to lessen the risks of inefficient trade diversion and asymmetric benefits. Present inconsistencies need to be eliminated through harmonization of the features adopted by different arrangements, including rules of origin, external tariffs, customs procedures, product standards, and the speed of convergence.

Ultimately, in the long run if all members of the RTAs in the sub-region are to reap the benefits of their membership, they should move beyond trade arrangements, like freetrade areas or customs unions, towards deeper integration schemes. In these more advanced ways of integration, static trade liberalization gains would not be the dominant consideration, but rather deeper integration would focus on the potential gains stemming from increased competitiveness through the reduction of administrative and transaction costs, and other barriers to trade of goods, services, and cross-border movements of labor and capital (Robson 1998).

\section{The Cotonou Agreement and its implications for the regional trade agenda}

One of the objectives of the Cotonou Agreement signed between the European Union and the African, Caribbean and Pacific group which replaces the Lomé Convention, is that the ACP member states enter into Economic Partnership Agreements (EPAs) with the European Union, either individually or collectively, taking into account the regional integration processes already in existence.

Negotiations of the EPAs were kicked off on September 27, 2002 and should end by December 31, 2007. EPAs will set out the timetable for the progressive removal of barriers to trade resulting in the establishment of Free Trade Areas (FTA) between the EU and ACP regional groups in accordance with the relevant WTO rules. Reciprocity will be introduced gradually and asymmetrically, with the EU removing most of its tariff barriers in a short period of time, with ACP tariff-dismantling starting in 2008 at the earliest. Moreover, EPA arrangements will take into account the level of development 
and socio-economic impact of trade measures on ACP countries, and their capacity to adapt to the liberalisation process -this is what is called differentiation. Negotiations will therefore be as flexible as possible regarding the duration of a sufficient transitional period, the final product coverage, sensitive sectors, and the degree of asymmetry, while remaining in conformity with WTO rules.

By 2006 there will be a review of the overall progress in negotiations with a view to ensuring that negotiations be concluded in time to allow EPAs to enter into force on 1 January, 2008 at the latest. A joint ACP-EC Ministerial Trade Committee will accompany the negotiations.

As a result EPAs will become the new agreements governing trade relations between the EU and ACPs, but their aim goes well beyond the mere negotiation and establishment of free trade areas, to deal with trade-related issues as well as development aspects. One of the reasons for the phasing out of the Lomé Convention and the negotiation of the Cotonou Agreement is the widespread perception that the Lomé trade arrangements, which through the Generalized System of Preferences (GSP) offers generous preferential access to EU markets, has not benefited most ACP countries. This is due to the fact that most ACP countries lack the productive and technological capacities, marketing skills, transportation channels, and appropriate technical and sanitary regulations to take advantage of improved market access.

Hence, the gradual integration of ACP into the world economy is one of the principal important objectives of the partnership between the EU and the ACP, as reflected in the Cotonou Agreement. According to the European Commission's (EC) guidelines for the EPAs negotiations, the development objective is a key component of the Cotonou Agreement. Indeed, Article XXXIV (1) of the Agreement clearly states that economic and trade cooperation between ACP and the EU "shall aim at fostering the smooth and gradual integration of ACP States into the world economy, with due regard to their political choices and development priorities, thereby promoting their sustainable development and contributing to poverty eradication in the ACP countries". EPAs are therefore an attempt to make use of the existing regional integration organizations to assist ACP countries to deal with many of the trade-related and supply-side problems that constrain their access to global markets.

Nevertheless, whether the Cotonou and EPAs are the most suitable instruments for ACP to achieve their intended goals is far from clear. Numerous authors have explicitly criticized them for the risk and possible negative effects they may bring to ACP countries in general and Africans in particular. It has been claimed that ACP countries will not gain many additional preferences than those that they already enjoy, while they will have to actually lower their tariffs to EU products which might have very serious consequences for ACP. In particular, some authors (Schiff 2002, Winters 2002), argue that EPAs will be trade diverting and will entail an important transfer of tariff revenues from ACP to EU producers, thus worsening their terms of trade and resulting in a net welfare loss. The reason being that since ACP imports from non-EU countries still will have to pay tariffs, prices are unlikely to fall and therefore EU producers will capture the tariff revenue while 
ACP consumers will not see any benefits. Several other studies estimate that the net impact of EPAs is likely to be negative (for a list of those studies, see Schiff 2002).

Other arguments raised against EPAs relate to the large direct costs that their negotiation and administration will require for ACP countries, diverting scarce resources from other uses like customs administration, domestic policy resource and particularly the multilateral trade negotiations (Winters 2002).

While these arguments should be taken into account attention should be shifted to the negotiations ${ }^{6}$. Given the fact that the Cotonou Agreement has already been signed in its current format, and as a result EPAs will have to be negotiated, focus should now be diverted to helping ACP countries effectively negotiate.

In this context, EPAs can provide a unique opportunity for the ACP countries to renegotiate fundamental changes to their trading relationship with the EU and with each other. From the start, it is clear that the EPAs will not simply focus on market access or tariff preference issues. In fact, as we saw, EPAs are and should be above all, a development instrument, and as such, trade should be subordinated to the developmental objective. Some key aspects of EPAs that have to be re-negotiated refer to tradefacilitation issues such as rules and certificates of origin and customs procedures, or others where the Cotonou Agreement provides for enhanced technical assistance like standards and quality assurance and accreditation, sanitary and phyto-sanitary procedures, and domestic regulation issues involving competition norms and investment policies. This will have important implications in two areas:

First, re-negotiating current rules of origin and customs procedures can have a particularly tremendous beneficial impact for many ACP countries, since they impose a heavy burden on many exporters from developing countries. Recent studies have shown that, due to the inability to comply with RoO, most EU imports from many developing countries which are eligible for preferential treatment under the System of General Preferences (SGP) actually enter the EU market under non-preferential tariffs (Brenton 2003). Therefore, a re-drafting of these regulations for ACP countries, towards less protectionist rules of origin and less stringent customs procedures and technical standards could result in a rapid increase of exports to EU markets.

Second, the emphasis on non-tariff issues provides an opportunity for the ACP states to link the negotiation and implementation of EPA's to further regional integration whilst engaging with the international economy. As mentioned, the Cotonou Agreement clearly sets out that EPAs will build on regional integration initiatives existing within the ACPs, at a level and in accordance with procedures agreed by the ACPs. It is then envisaged that there will be different agreements between different regions, and negotiations will take

\footnotetext{
${ }^{6}$ One theoretical argument in favor of EPAs is that it belongs to the category of North-South agreements, which, as recent literature suggests, leads to income convergence (World Bank 2000) and larger R\&D spillovers on productivity than South-South agreements (Schiff 2002b). This effects would be tempered by the fact that in this case the EU, through the SGP system has already given free market access to most ACP products.
} 
place (with one or two exceptions of countries that may negotiate on their own) with groups of countries already engaged in a process of regional integration. ACPs should then decide their preferred geographical configurations before negotiations can start in earnest. In 2004, the situation of non-LDC ACP countries that do not consider themselves to be in a position to enter into EPAs will be examined.

In summary, it is clear there are still many issues that need to be clarified if the region is to have meaningful negotiations with the EU, compatible with WTO regulations and in line with the development objectives of the Cotonou Agreement. Some of the most relevant ones are the following:

\section{(i) EPAs and Everything But Arms Initiative (EBA):}

The so-called Everything-but-Arms Initiative was approved by the European Union in February 2001. It contemplates the immediate elimination of all quotas and duties on all products (free access for rice, sugar and bananas will be introduced after a transition period) except arms and ammunition imported into the EU from the world's 48 LeastDeveloped Countries or LDCs.

The EBA initiative has, in general, been welcomed by the ACP LDC countries. There is, however, a concern in some countries that it will make it more difficult to negotiate regional EPAs and may well have weakened the African regional integration process. Allowing better access into EU markets for LDCs compared to developing countries may reduce the interest of LDCs to join with other developing countries in a regional integration organisation to form an EPA. As all LDCs now have duty-free access into the European market, if an LDC prefers to opt for a more shallow form of integration with the EU, this improved market access, coupled with resources provided under the European Development Fund, may satisfy the trade relation requirements of the LDC with the EU. If this is the case, there will be no incentive for LDCs members of regional agreements to enter into regionally-based EPA negotiations with the European Commission. In this regard, the EU has already accepted that the least developed countries will not experience a decline in trade preferences even in the event that they do not negotiate an EPA. Here lies one of the main challenges of EPAs -how to make differentiation for some countries compatible with the reinforcing and consolidation of regional integration processes.

In the event that developing countries are unable to agree on an EPA as an alternative trading arrangement, it is assumed that the EU would still offer EBA treatment to their imports. Despite this fact, there are a number of important reasons why LDCs may want to join the EPA negotiations. First, EBA is an EU unilateral initiative and, as such, could be unilaterally removed without negotiation or notification.

More importantly its rules of origin are less liberal than those currently applying to ACP countries under the Cotonou Agreement and will likely be even more restrictive than those negotiated in the EPAs. In particular, contrary to the Cotonou rules, EBA rules of origin do not allow for diagonal cumulation of intermediate factors between ACP 
countries. This probably largely explains why ACP countries', use of EBA preferences in 2001, the first year of the initiative, was less than $5 \%$ of the exports eligible for it (Brenton 2003). Most: EBA countries prefer to continue exporting to the EU under the Cotonou regulations, but this will not be possible in the future unless they enter into an EPA with the EU. In fact, EPAs offer the possibility of negotiating even simpler and less protectionists rules of origin.

In addition, EBA does not provide for a comprehensive package of support for regional integration and economic development aimed at integrating ACP economies into the world economy.

\section{(ii) EPAs and WTO negotiations}

A number of areas to be addressed in EPAs are also on the WTO agenda that came out of the Doha meeting, which might reduce even more the incentives for some countries to engage in EPAs. There is some concern in Africa that EPA negotiations will not bring much value added if the same issues are negotiated simultaneously under the WTO umbrella. Conversely, if an agreement is reached under EPAs before agreement is reached in the WTO, and if the decision reached under EPA negotiations is inconsistent with that subsequently reached under WTO, it is assumed that the part of the EPA agreement which is inconsistent with the WTO decision will need to be renegotiated. However, there are some advantages to engaging in EPA negotiations instead of the multilateral Doha Round. In particular in EPA negotiations, ACP countries or regional groups can decide the level and procedures more appropriate for their needs, and will have more leverage than in the WTO. Moreover, EPA negotiations are bound to a specific time frame, whereas multilateral rounds can drag on.

\section{(iii) The implications for $S A C U$}

The SACU is an existing customs union and the EU has recently concluded a Free Trade Agreement with South Africa, which specifies that the SACU Common External Tariff will be phased down for EU imports. Therefore, the BLNS as members of SACU will be de facto engaging in a reciprocal trade agreement with the EU through the FTA according to modalities already decided in the EU-SA FTA. However, BLNS market access to the EU is governed currently by the Cotonou Agreement, and after 2008, by the result of the EPA negotiations. In the event that the BLNS are unable to agree to an EPA, Lesotho would continue to enjoy unchanged preferential access to the EU under the EBA initiative while Botswana, Namibia and Swaziland would (presumably) revert to current $\mathrm{GSP}^{7}$ status.

The current situation, with a member of a Customs Union signing bilaterally a FTA with another country is clearly anomalous and has important consequences for the BLNS countries. On one hand, by reducing the tariff revenues that SACU collects as a whole the SA-EU FTA reduces the current amount BLNS receive from the common SACU revenue pool. In fact, this is one of the main reasons for the recent renegotiation of the SACU revenue-distribution formula in a way that is even more favorable to BLNS countries. On

${ }^{7}$ General System of Preferences 
the other hand, the current scenario, with BLNS removing their tariffs to EU products as a result of the EU-South Africa FTA is not consistent with the development objectives of the Cotonou Agreement mentioned above, which are based on asymmetric concessions and gradual integration of ACP into the world economy according to their needs. Yet, an attempt from the BLNS countries to impose strict controls at their borders with South Africa to avoid triangulation of EU products entering their markets would be extremely costly and would eliminate many of the benefits derived from the free flow of goods in SACU.

It is therefore necessary to identify alternative scenarios for the BLNS. One option is for the BLNS to ask to join the EU-South Africa FTA. This has many advantages, for it would keep all SACU members in one agreement, thus removing the complexity of having one member of the SACU agreeing to a Free Trade Area with a third party. There is some case against this solution on the basis that the EU-South Africa FTA took four years and 21 rounds of talks to negotiate and hence, the final outcome represents the interests of both parties which do not necessarily coincide with those of BLNS. Therefore, it is been argued that a SACU-EU tariff dismantling should take into account the interests of the BLNS. There are at least three arguments against the latter: first, although the SA-EU FTA was negotiated by the South African Government, regular consultations took place during the process with the BLNS partners, in an attempt to address their main concerns; second, reopening negotiations could risk unraveling the Agreement and would introduce a degree of uncertainty for investors. Finally, this option, by splitting SACU countries from the rest of SADC would put a break on SACU-SADC regional integration, which goes against the spirit of the Cotonou Agreement.

A further option would be for the BLNS to consider themselves party to a broader EPA which would include the whole or part of Eastern and Southern Africa and that over time would be aligned with the EU-SA FTA. This would allow for the BLNS to negotiate a two-year extension on their market access to the EU (i.e. from 2008-2010). The latter would be consistent with their de facto phased removal of tariffs under the SA-EU FTA. By remaining outside the EU-SA FTA it allows for the BLNS to enter into negotiations on trade facilitation and non-tariff issues as part of a broader regional EPA. However, looking forward, it is easy to expect that SACU's neighbors may be uneasy about the implications of joining in an EPA with Botswana, Lesotho, Namibia or Swaziland due to fears of leakage from the EU-SA FTA. In summary, there is not an obvious answer to the question of how SACU agreement will fit into the forthcoming regional trade agenda.

\section{(iv) The problem of overlapping and conflicting Regional Trade Agreements.}

The inconsistencies built into the various regional trade accords in Southern and Eastern Africa, and in particular the inconsistencies mentioned above between the trade regimes of COMESA, SADC, EAC and SACU, are one of the main constraints directly affecting the negotiations of EPAs. The Cotonou Agreement explicitly states that EPAs should take into account the regional integration process currently taking place. However, the current situation of countries offering a variety of MFN, preferential and potentially common external tariffs, makes it difficult to see how countries or groups of countries 
belonging to several RTAs can get together and negotiate a single- or a few EPAs- with the EU. The need for harmonization and rationalization is now an imperative for the region.

\section{(v) EPAs modalities of negotiations:}

The Cotonou Agreement explicitly leaves to the ACP countries to decide on the level and procedures of the EPA trade negotiations. However, purely for logistical reasons it is unlikely that the EU will be able to enter into many negotiations with individual countries, while at the same time few ACP countries will have the capacity to enter into negotiations on their own with the EU. Therefore, except for perhaps one or two ACP countries, that might have the capacity to negotiate on their own, it appears that negotiations will take place with several countries forming sub-regional groups.

It is thus widely accepted that EPA negotiations will be conducted at two levels: the issues common to most countries will be addressed at the all-ACP level, whereas the subregion specific issues will be negotiated at the sub-regional level. This seems to be a good approach, allowing regions that are better prepared and want to move faster to do so by negotiating separately with the EU.

One option for negotiations at the sub-regional level, would be for the negotiations to be conducted along the lines of the regional trade agreements. However, lack of capacity on the part of the regional organizations and the afore mentioned problem of the overlapping memberships and contradictory commitments make it very difficult for regional organizations to negotiate EPAs on behalf of their member states. For example, in the case of SADC, it is doubtful that all its member states can negotiate as a group when ten members out of 14 may be members of three different customs unions from 2004.

Moreover, the different and asymmetric trade relationship that countries in the subregion maintain with the EU complicates further the task of negotiating EPAs on the basis of the existing regional organizations. For example, it is not clear whether SADC Member States are expected to negotiate as a group minus South Africa, since (as noted above) South Africa already has a legally binding trade agreement with the EU. The same applies to COMESA with Egypt, which is not ACP country. Another unresolved issue is what would happen to some countries when they graduate from LDC status. If the EU decides to discontinue their duty free access for them under the EBA initiative, it is not clear whether these countries would automatically join the existing EPAs that they might not have negotiated. On the other hand, it is doubtful that SADC or COMESA countries that do not benefit from EBA or the EU-SA FTA will find it in their best interest to leave negotiations to either regional organization whose majority members might not have the same interest in the EPA. It is thus inconceivable for SADC to develop an independent negotiating mandate on behalf of its Member States that would result in a WTO compatible Free Trade Area with the EU by 2020.

Once the possibility of negotiating by RTAs is ruled out, the critical issue is to decide on a criterion for grouping the countries in the region to be covered by the same EPA. The 
best outcome for the region would be to negotiate an EPA that encompasses as many countries as possible, and if possible negotiate a single EPA for the whole region. The countries of Eastern and Southern Africa should join forces and try to use the opportunity that the EPA negotiations bring about to generate a political "Big Bang" signal that the region is moving firmly in the direction of regional trade liberalization and integration into the world economy. This "Big Bang" means moving steadily towards a free trade area for the whole ESA Region, which then negotiates an EPA with the EU. A single EPA for southern and eastern Africa could be envisioned by 2008 provided that, at a minimum, the regional trade regimes are made compatible, and preferably harmonized. A negotiating party involving so many countries could be difficult to manage, but on the other hand, it would definitively wield a lot more negotiating leverage vis a vis the European Union than several smaller fractioned groups. Ultimately, negotiating a single EPA that encompasses all the regional groupings in the sub region would require to seriously deal with the overlapping and contradictory commitments embedded in the RTAs. This would entail at the minimum the following:

- $\quad$ The regional grouping doing the negotiations should have a structured and compatible trade framework with a free trade area as an absolute minimum, and preferably a customs union or at least harmonized low external tariffs, so that there is less danger of trade diversion taking place. Several of the regional organizations either constitute a customs union or will be customs unions (or free trade areas) by the time EPAs come into force so, theoretically, they could effectively join to negotiate EPA. For example, if EAC and COMESA established the same Common External Tariff this would allow them to negotiate a joint EPA. For SADC, the implementation of a Customs Union seems further down the road. In this case, SADC (non-COMESA) members should move unilaterally towards aligning their MFN tariffs as close as possible to those of the COMESA/EAC Customs Union, thus reducing the scope for product triangulation taking advantage of the tariff rate differentials. COMESA, EAC and SADC have already constituted joint task forces at the technical level to address the problems arising from their differing trade agendas, and therefore what is needed is the political impulse to move further down the path of harmonization that could very well arise from the urgency of the EPA negotiating calendar. Ideally, by the time the implementation of the EPAs start in 2008, ESA region should have achieved a regional free trade area and a high degree of convergence across countries in their external tariffs. This would simplify and facilitate the negotiation of a single calendar for eliminating tariffs for European products. Rather than negotiating country by country or product by product, one option could be to agree on percentage tariff cuts across the board for all ESA countries with a minimum and uniform number of products excluded.

- Rules of origin should be harmonized among the RTAs towards the simpler and less protectionist ones, and full diagonal cumulation should be permitted in any potential EU-ESA EPA so as to foster the use of regional inputs and creation of backward linkages across the region. As indicated, Regional Trade Agreements require rules of origin because different tariffs are imposed on similar goods in accordance with their origin of "production". However, they are often used as ways of hidden protectionism inserted in regional agreements. Moreover, they are becoming a source of considerable complexity 
and confusion, imposing a heavy burden on customs administrations and eliciting corruption and rent-seeking. Simplification, harmonization and diagonal cumulation of rules of origin will therefore reduce the room for bribery and the administrative cost, and encourage local firms to use regional inputs in the production of their products.

- Non-tariff barriers to trade should be eliminated across Eastern and Southern Africa. This is a critical issue that has been neglected to a large degree in past regional trade negotiations. Yet, unless the multiple NTBs that the countries currently impose are seriously tackled, there will not be significant increases in regional trade flows no matter how much tariffs are lowered. NTBs encompass a wide range of issues that go well beyond pure trade matters, such as trade finance and market information. Here we refer primarily to removing border barriers, which implies streamlining customs procedures, harmonizing customs documentation and certificates of origins, and establishing a well functioning single transit-transport regime with a regional transit-bond guarantee system. Also, in the area of sanitary and phyto-sanitary (SPS) measures as well as technical standards (TS) to trade, countries should agree to stop using them for protectionist purposes. Since full harmonization would be a costly and lengthy process, governments could work towards a regional agreement on mutual recognition on SPS and TS. The main transport corridors that currently carry most of the international trade within the region, like the Maputo corridor or the Northern Corridor linking Mombassa to Bujumbura present the ideal framework to start implementing these measures. The agenda described would be expensive and the question of funding is critical. Multilateral and bilateral donors are already funding transit and trade facilitation projects across the region and, if the political decisions to eliminate NTB were taken, they could be mobilized to step up their financial support and expertise in favor of this agenda.

The agenda above describes a number of unresolved issues in the regional integration process that need to be dealt with urgently, and which will require the strong political commitment that has been lacking in the past. Indeed, most RTAs in ESA have not been really effective in advancing regional integration and promoting trade and development because ultimately, in spite of their rhetoric, countries were not always fully committed to the regional agendas and the implementation of treaties has been sluggish at best and simply non-existent in some cases. During the last few years there has been a relaunching of regional trade initiatives with some significant achievements, as witnessed by the launching of the COMESA FTA, the signing of the SADC Trade Protocol and the negotiation to re-establish the former EAC Customs Union. Yet, even in these cases progress is still very slow; only half of the COMESA countries participate in the FTA; SADC trade protocol is still not in place; and in the EAC case, while countries are negotiating a customs union they still impose surcharges and suspended duties on their bilateral trade.

The market fragmentation and low demand of most countries in the region makes regional economic integration an appropriate means for promoting intra-regional trade and accelerating growth and structural transformation through economic diversification. Yet, the main reason that lies behind the lack of commitment to the regional integration process is the continuous focus of many countries on the costs that it imposes, and the 
misgivings about the opportunities it could bring about. Many governments see it as a zero-sum game whereby what a country achieves in terms of market access is at the expense of the neighbor, which translates into deep reluctance to open domestic markets to regional partners. Lack of commitment also explains to a large extent why most countries belong to more than one RTA, with little consideration to their conflicting trade schedules and regimes, many of which ultimately will not be implemented.

Notwithstanding, the Cotonou Agreement presents a window of opportunity to overcome all these political obstacles and advance firmly the regional integration process in Eastern and Southern Africa. As explained, EPAs offer all ACP countries the possibility of a serious improvement in the relations with the EU. But Eastern and Southern Africa needs to do its homework first, because unless ESA countries take decisive steps towards deeper integration, including rationalization and harmonization of the current "spaghetti bowl" of regional trade agreements, it is very doubtful that they will be in a position to negotiate a single EPA encompassing all of them. If this is the case, there is a great risk that the whole process will fail or that the countries will embark on several fractioned negotiations with the EU, that ultimately will not produce the benefits that EPAs could potentially generate. Governments will have to show political leadership to move this agenda forward and fully harness all the potential benefits that EPAs present. This is too good an opportunity for Africa to miss.

\section{Conclusions}

The RTAs that have proliferated in Eastern and Southern Africa can, if properly designed and effectively implemented, be an important instrument to assist the member countries in increasing their current low trade links and integrating with global markets. The reality is nonetheless, that these arrangements are characterized by their multiple and overlapping membership, and complex structures - and eventually conflicting and confusing commitments. Past attempts to rationalize and harmonize the current Regional Trade Agreements have failed because ultimately many countries were not committed to regional integration and more generally to trade liberalization, and they did not see clear benefits from the rationalization.

However, the Cotonou Agreement provides an excellent and decisive window of opportunity for the region to organize itself and to harness the benefits stemming from the future Economic Partnership Agreements. EPAs offer all ACP countries the possibility of a complete overhaul of trade relations with the EU in a way that could have serious benefits for them. It has been argued that EPAs may weaken, rather than strengthen, the regional integration process in Southern Africa as it will force countries to decide on regional configuration and a common negotiating mandate. It is not EPAs which will force this issue, but the internal contradictions of the regional trade accords themselves. In fact, the benefits accruing from the Cotonou Agreement and EPA negotiations are so important that they can be the external driving force that will push the regional organizations to rationalize and harmonize their trade regimes. 
Therefore, unless ESA. countries reform and harmonize their regional trade agreements in a way that will permit the negotiation of a single EPA for the whole region, there is a great risk that negotiations will fail or multiple negotiations will take place by subgroups of countries and, as a consequence, they will not produce the results expected Africa will then miss the opportunity to improve its integration into the world economy. Governments will have to show political leadership to move this agenda forward and fully harness the potential benefits that EPAs present. 


$\begin{array}{ll}\text { ACRONYMS AND ABBREVIATIONS } \\ \text { ACP } & \text { Africa, Caribbean, Pacific group } \\ \text { BLNS } & \text { Botswana, Lesotho, Namibia and Swaziland } \\ \text { CBI } & \text { Cross-Border Initiative (See RIFF) } \\ \text { CEMAC } & \text { Communauté Economique et Monétaire de l'Afrique Centrale } \\ \text { CET } & \text { Common External Tariff } \\ \text { CMA } & \text { Common Monetary Area } \\ \text { COMESA } & \text { Common Market for Eastern and Southern Africa } \\ \text { CU } & \text { Customs Union } \\ \text { DRC } & \text { Democratic Republic of Congo } \\ \text { EAC } & \text { East African Community } \\ \text { ECOWAS } & \text { Economic Community of West African States } \\ \text { EDF } & \text { European Development Fund } \\ \text { EC } & \text { European Commission } \\ \text { EPA } & \text { Economic Partnership Agreement } \\ \text { ESA } & \text { Eastern and Southern Africa Region } \\ \text { EU } & \text { European Union } \\ \text { FDI } & \text { Foreign Direct Investment } \\ \text { FTA } & \text { Free Trade Area } \\ \text { GATT } & \text { General Agreement on Trade and Tariffs } \\ \text { GDP } & \text { Gross Domestic Product } \\ \text { IMF } & \text { International Monetary Fund } \\ \text { IOC } & \text { Indian Ocean Commission } \\ \text { LDC } & \text { Least Developed Country } \\ \text { NTB } & \text { Non-Tariff Barriers } \\ \text { RTA } & \text { Regional Trade Arrangement } \\ \text { RIFF } & \text { Regional Integration Facilitation Forum } \\ \text { RoO } & \text { Rules of Origin } \\ \text { SA } & \text { South Africa } \\ \text { SACU } & \text { Southern Africa Customs Union } \\ \text { SADC } & \text { Southern African Development Community } \\ \text { SGP } & \text { System of Generalised Preferences } \\ \text { SPS } & \text { Sanitary and Phito-sanitary Measures } \\ \text { TS } & \text { Technical Standards } \\ \text { USA } & \text { United States of America } \\ \text { WAEMU } & \text { West African Economic and Monetary Union } \\ \text { WB } & \text { World Bank } \\ \text { WTO } & \text { World Trade Organization } \\ & \end{array}$




\section{Bibliography:}

Breton Paul and Manchin M. Making EU Trade Agreements work: The role of rules of origin. Center for European Policy Studies. Working Paper 183. Brussels, 2002.

Brenton Paul Integrating the Least Developed Countries into the World Trading System: The Current Impact of EU Preferences under Everything But Arms. World Bank Policy Research Paper 3018. April 2003. Washington, DC.

Cadot, Olivier, de Melo Jaime, and Olarreaga Marcelo: Asymmetric Regionalism in Sub-Saharan Africa: Where do we stand?. CEPR Discussion Paper 2299. November 1999.

COMESA Secretariat: Discussion paper on trade policy compatibility and impact assessment of economic partnership agreements and preliminary adjustment scenarios. Lusaka, January 2002.

European Commission: ACP-EU Partnership Agreement signed in Cotonou on 23 June 2000. The Courier special issue, September 200.

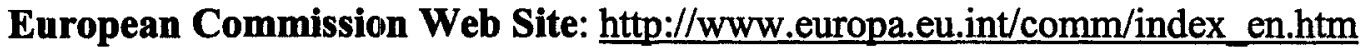

Flatters, Frank: SADC Rules of Origin: Undermining Regional Free Trade. Queen's University, Canada. Paper prepared for TIPS Forum, Johannesburg, South Africa, September 9-11, 2002.

Gelb, Alan: Planning Africa's Development in the $21^{\text {st }}$ Century. Paper prepared for Planning Africa Conference Durban, September 17-20, 2002.

IMF: Trade and Trade Policies in Eastern and Southern Africa. Occasional Paper No. 196. Washington DC, 2000.

Messerlin P. and Maur. Jean-Christophe, Which Free Trade Agreements in South Eastern Europe. Technical Report for the Working Group on Trade of the Stability Pact. March 2001

Robson, Peter: The Economics of International Integration. London; New York, Routledge, 1998.

Schiff, Maurice: Regional Integration and Development in Small States. World Bank Working Papers No. 2797. Washington, March 2002.

Schiff, Maurice, Y. Wang and M. Olarreaga: Trade-Related Technology Diffusion and the Dynamics of North-South and South-South Integration. World Bank, Policy Research Working Paper 2861. June 2002 
UNCTAD: World Investment Report 2002: Trasnational Coorporations and Export Competitiveness. New York and Geneva, 2002

Venables J. Anthony: Winners and losers from regional integration agreements. Center for Economic Policy Research (CEPR). Discussion Paper Series No. 2528:1-[26], (U.K.); August 2000.

Willem Gunning, Jan: Trade Blocks: Relevant for Africa?. Journal of African Economies, Volume 10, No. 3. Oxford, 2002.

Winters, Alan: Doha and the World Poverty Targets. Paper presented at the Annual Bank Conference on Development Economics. The World Bank, Washington April, 2002.

Wood, Adrian and Jörg Mayer (2001) Africa's Export Structure in a Comparative Perspectiv., Cambridge Journal of Economics Vol. 25, No. 3, May, pp. 369-94

World Bank, Can Africa Claim the 21st Century. Oxford Press. Washington DC, 2001.

World Bank: Regional integration in Southern Africa: Overview, Challenges and Recent Developments. Background Paper, unpublished. Washington 2001.

World Bank. Trade Blocs. World Bank Policy Research Report. Washington D.C. 2000.

Yagci, Fahrettin and Enrique Aldaz-Carroll. Trade Performance in Eastern and Southern Africa. As part of Trade Policies and Performance in Eastern and Southern Africa. Mimeo 2003. Washington, DC.

Yeats, Alexander J.. What Can Be Expected From African Regional Trade Arrangement? Some Empirical Evidence. The World Bank. Policy Research Working Paper, No 2004. Washington D.C., 1998. 


Title WPS3071 Survey Techniques to Measure and
Explain Corruption

WPS3072 Diversity Matters: The Economic Geography of Industry Location in India

WPS3073 Metropolitan Industrial Clusters: Patterns and Processes

WPS3074 The Gender Impact of Pension Reform: A Cross-Country Analysis

WPS3075 Child Labor, Income Shocks, and Access to Credit

WPS3076 Trade Reform in Vietnam: Opportunities with Emerging Challenges

WPS3077 Do More Transparent Governments Govern Better?

WPS3078 Regional Integration in East Asia: Challenges and OpportunitiesPart I: History and Institutions

WPS3079 Regional Integration in East Asia: Challenges and OpportunitiesPart II: Trade, Finance, and Integration

WPS3080 Can Fiscal Rules Help Reduce Macroeconomic Volatility in the Latin America and Caribbean Region?

WPS3081 The Anatomy of a Multiple Crisis: Why was Argentina Special and What Can We Learn from It?

WPS3082 Financial Dollarization and Central Bank Credibility

WPS3083 Mine Closure and its: Impact on the Community: Five Years after Mine Closure in Romania, Russia, and Ukraine

WPS3084 Major Trade Trends in East Asia: What are their Implications for Regional Cooperation and Growth?

WPS3085 Export Profiles of Small Landlocked Countries: A Case Study Focusing on their Implications for Lesotho

WPS3086 Intertemporal Excess Burden, Bequest Motives, and the Budget Deficit
Author

Ritva Reinikka

Jakob Svensson

Somik V. Lall

Jun Koo

Sanjoy Chakravorty

Sanjoy Chakravorty

Jun Koo

Somik V. Lall

Estelle James

Alejandra Cox Edwards

Rebeca Wong

Kathleen Beegle

Rajeev H. Dehejia

Roberta Gatti

Philippe Auffret

Roumeen Islam

Eisuke Sakakibara

Sharon Yamakawa

Eisuke Sakakibara

Sharon Yamakawa

Guillermo Perry

Guillermo Perry

Luis Servén

Kevin Cowan

Quy-Toan Do

Michael Haney

Maria Shkaratan

Francis $\mathrm{Ng}$

Alexander Yeats

Francis $\mathrm{Ng}$

Alexander Yeats

Derek Hung Chiat Chen

Dert
June 2003

Date

June 2003

June 2003

June 2003

June 2003

June 2003

June 2003

June 2003

June 2003

June 2003

June 2003

June 2003

June 2003

June 2003

June 2003

June 2003
Contact

for paper

H. Sladovich 37698

V. Soukhanov 35721

V. Soukanov 35721

M. Ponglumjeak 31060

E. de Castro 89121

K. Tomlinson 39763

R. Islam 32628

S. Yusuf 82339

S. Yusuf 82339

R. Izquierdo 84161

R. Izquierdo 84161

Q. Do 34813

L. Marquez 36578

P. Flewitt 32724

P. Flewitt 32724

D. Chen 81602 


\section{Policy Research Working Paper Series}

\begin{tabular}{|c|c|c|c|c|}
\hline & Title & Author & Date & $\begin{array}{l}\text { Contact } \\
\text { for paper }\end{array}$ \\
\hline WPS3087 & $\begin{array}{l}\text { Gender, Generations, and Nonfarm } \\
\text { Participation }\end{array}$ & $\begin{array}{l}\text { M. Shahe Emran } \\
\text { Misuzu Otsuka } \\
\text { Forhad Shilpi }\end{array}$ & June 2003 & $\begin{array}{l}\text { P. Kokila } \\
33716\end{array}$ \\
\hline WPS3088 & $\begin{array}{l}\text { U.S. Contingent Protection against } \\
\text { Honey Imports: Development Aspects } \\
\text { and the Doha Round }\end{array}$ & Julio J. Nogués & June 2003 & $\begin{array}{l}\text { P. Flewitt } \\
32724\end{array}$ \\
\hline WPS3089 & $\begin{array}{l}\text { The "Glass of Milk" Subsidy Program } \\
\text { and Malnutrition in Peru }\end{array}$ & $\begin{array}{l}\text { David Stifel } \\
\text { Harold Alderman }\end{array}$ & June 2003 & $\begin{array}{l}\text { H. Sladovich } \\
37698\end{array}$ \\
\hline
\end{tabular}

